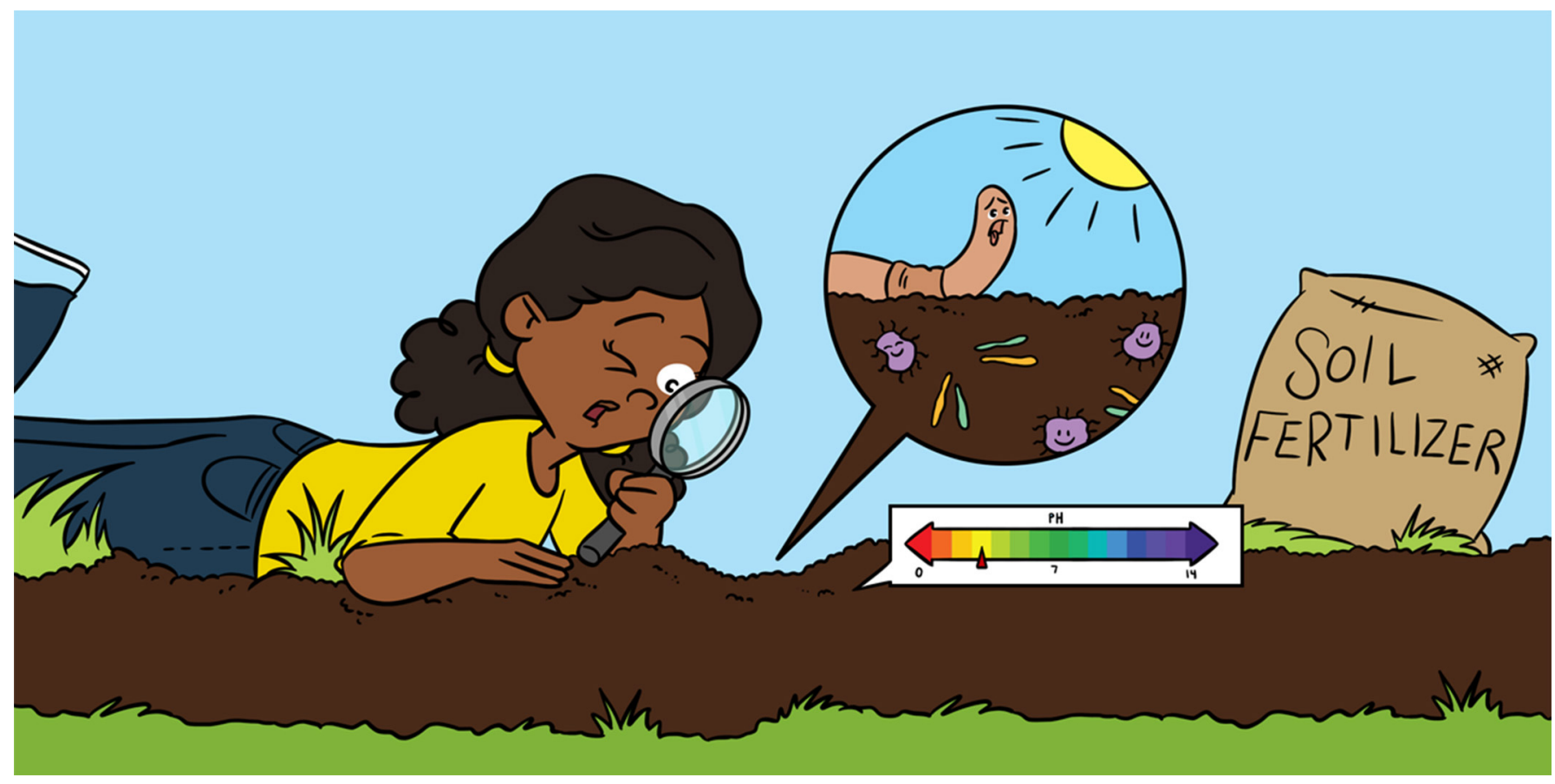

\title{
DOUBLE WHAMMY FOR LIFE IN SOIL? THE EFFECTS OF DROUGHT AND FERTILIZER USE
}

\author{
Marie Sünnemann $^{1,2^{*}}$, Julia Siebert $^{1,2}$ and Nico Eisenhauer ${ }^{1,2}$ \\ ${ }^{1}$ Experimental Interaction Ecology, German Centre for Integrative Biodiversity Research (iDiv) Halle-Jena-Leipzig, Leipzig, \\ Germany \\ ${ }^{2}$ Institute of Biology, Leipzig University, Leipzig, Germany
}

\section{YOUNG REVIEWER:}

JEDIDIAH

AGE: 14
For the last two centuries, humans have been changing the Earth through their way of life. Our actions are not only causing climate change and leading to prolonged periods of drought, they are also leading to an overaccumulation of nutrients in soil, due to burning of fossil fuels and fertilization of agricultural fields. Both factors are threatening the world beneath our feet: the soils. They may look rather boring and lifeless, but soils are actually home to many organisms-from tiny bacteria to agile millipedes and slimy earthworms-all of which contribute to processes that are indispensable to life on Earth. For example, the activity of these organisms promotes decomposition of plant material, which ensures that the farmlands on which we grow our food remain fertile. As almost all soil organisms are very sensitive to changes in their environments, we wanted to know what would happen if drought and over-fertilization occurred together. 


\section{ECOSYSTEM}

A community of plants, bacteria, animals, and fungi in a certain location, along with the non-living components of that environment.

\section{INVERTEBRATES}

Animals lacking spines, such as centipedes, woodlice, and earthworms.

\section{ECOSYSTEM}

\section{FUNCTIONS}

Natural processes that occur in an ecosystem

\section{DECOMPOSITION}

After death, living organisms are broken down into smaller and smaller pieces. This releases nutrients, which in turn are needed for plant growths.

\section{HUMAN ACTIVITIES CHANGE ECOSYSTEMS}

Over the last 200 years, human activities have changed the world tremendously. Human-induced climate change is causing the planet to warm up, coupled with ever-longer periods of drought (prolonged periods with little rainfall) in some regions. At the same time, the farming of fields and meadows has changed dramatically in recent decades. The world's population is growing steadily, and all these many people need to eat. Therefore, large amounts of fertilizers are applied on agricultural fields today, resulting in much higher crop yields [1]. While they may provide enough food for several billion people, these practices come with a significant drawback: similar to drought, excess fertilization affects not only the plants visible aboveground, but also the complex ecosystem belowground-the soil and the organisms living in it.

\section{THE IMPORTANCE OF THE SOIL ECOSYSTEM}

Soils are an important part of terrestrial ecosystems. Although we are often unaware of them, soils are teeming with living things. There are microorganisms, such as bacteria and fungi that are so tiny that they are not visible to the naked eye. What they lack in size, however, they compensate for in number: just one teaspoonful of soil can contain several million soil microorganisms. Even many of the somewhat larger creatures, such as mites and springtails, can only be seen with a magnifying glass. Among the biggest soil animals are woodlice, centipedes, and earthworms. All the somewhat larger soil creatures are united by the fact that they do not have backbones, which is why they are referred to as invertebrates. These creatures live together in the soil and interact in various ways: some feed on each other, while others work together.

The soil invertebrates perform numerous tasks that are necessary for our existence. One of the most important of these ecosystem functions is decomposition, which requires the cooperation of a multitude of creatures. Soil organisms are responsible for the breakdown of dead plant material. Withered leaves, dead roots, and seeds are their food resources. They break down these dead plant materials into smaller and smaller pieces. The resulting tiny compounds, in turn, provide an excellent food source for soil microorganisms like bacteria and fungi. Eventually, these resources are converted back into a form that plants can use for their growth, namely $\mathrm{CO}_{2}$ and nutrients.

All these soil creatures, like almost all life on earth, are highly dependent on water for drinking, for breathing, or even as a means of transportation. Increasingly long and frequent periods of drought are therefore a problem for many small organisms. And even worse, what happens if other harmful factors occur at the same time? Excessive 
Figure 1

In half of the experimental plots in our study, we used roofs to simulate drought. The other half of the plots received "fake" roofs with rain panels put upside-down to account for the potential side effects of these roof structures (like changes in wind speed and light). ( Julia Siebert.

\section{PH VALUE}

A scale indicating whether a solution has an acidic or basic character. The lower the value, the more acidic the solution is.

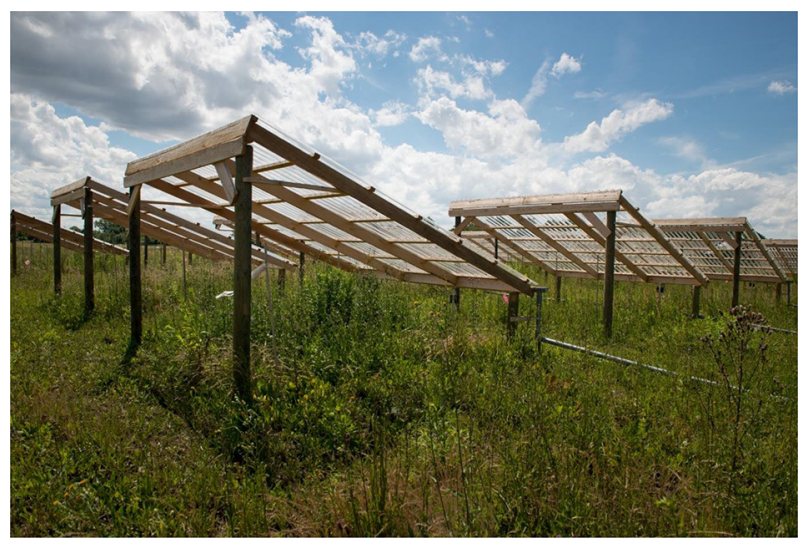

Figure 1

use of fertilizer, for example, can be harmful to soil organisms, as it changes the $\mathrm{pH}$ value of the soil to make it more acidic. Many soil organisms cannot tolerate acidic soil conditions. Could fertilization add a further stress factor, making it even harder for soil organisms to withstand dry conditions? And how exactly can we learn whether drought and fertilization are harmful to soil organisms and interfere with their functions?

\section{HOW DID WE STUDY SOIL MICROORGANISMS?}

To understand the effects of drought and fertilization on soil organisms, we started an experiment that simulated these two common factors that humans change [2]. We chose a meadow in Central Germany where we selected small areas called experimental plots and treated the plots in different ways. One-fourth of the experimental plots were treated with drought using roofs (Figure 1), another fourth was treated with fertilizer, and yet another fourth was treated with a combination of drought and fertilizer. The last fourth was not treated at all, which was our control plot. Control plots are important because they allow us to compare the treatments to normal conditions.

To understand how drought and fertilization affect soil organisms, we looked at soil invertebrates and soil microorganisms separately. We examined the activity of soil invertebrates in each of our plots. To do this, we used narrow plastic strips with several small holes in them, called bait lamina test strips. Every hole was filled with a bait mixture, which soil invertebrates like to eat-imagine invertebrate cereal. We stuck some bait lamina test strips completely into the ground of our plots (Figure 2). After 3 weeks, we observed the amount of the bait that had been eaten by the soil animals. Soil ecologists use this method to assess how much soil invertebrates eat, which is a very good indicator of their activity in general. 


\section{Figure 2}

To determine the activity of soil invertebrates in our experimental plots, we used bait lamina strips. The strips were completely inserted into the ground for soil invertebrates to feed on. After 3 weeks, we checked how many of the little holes containing the bait were full, empty, or half-empty. The more active and hungrier the soil invertebrates, the more of the bait was eaten.

(c) Gottschall/Siebert.

\section{BIOMASS}

Measure for the amount of all microbes that live in a defined amount of soil.

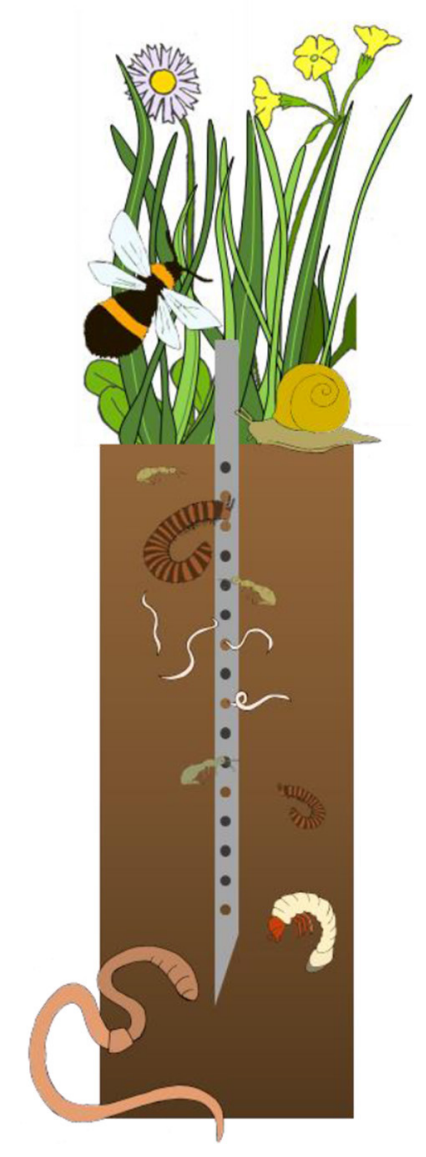

Figure 2

To examine the soil microorganisms more closely, we took a small amount of soil from each of our plots back to the lab. We determined the microbial activity in these samples by measuring their respiration. Just like humans, soil organisms breathe in oxygen $\left(\mathrm{O}_{2}\right)$ and exhale carbon dioxide $\left(\mathrm{CO}_{2}\right)$, so the more respiration that is happening in a sample, the more active are the microorganisms (think of yourself exercising). To measure microbial respiration, we used a device with a special sensor that can measure the amount of oxygen used by the microorganisms, and these data were then transferred to a computer for storage. By knowing the activity of the soil microorganisms, we were then able to calculate their biomass, which is a measure for the amount of all microbes that live in a defined amount of soil, for example on a teaspoon.

\section{DROUGHT AND FERTILIZATION CAN AFFECT SOIL INVERTEBRATES}

We used statistical tests on our data to find out how the microbial and invertebrate soil communities reacted to drought and fertilization. We found that both drought and fertilization severely disrupt the activity of soil invertebrates. Although the factors on their own had strong 
Figure 3

What did we find? (A) Drought, fertilization, and both together strongly reduced the feeding activity of soil invertebrates. (B) Soil microorganisms were not disturbed by the drought treatment. Fertilization caused an increase in the soil microbial biomass.

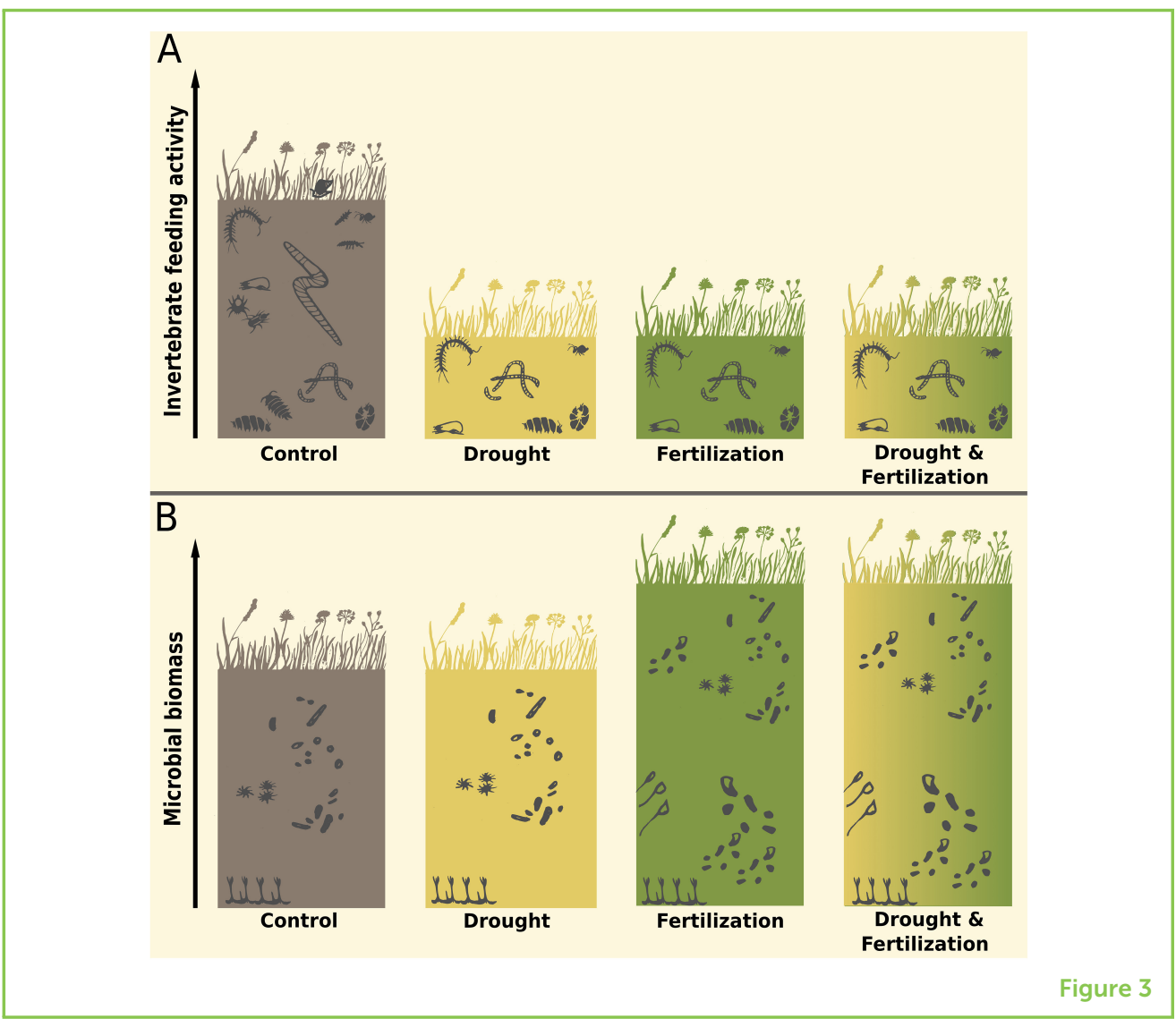

negative effects, their combination did not reduce invertebrate activity any further (Figure 3A). Soil microbes, however, reacted completely differently. Drought could not harm them, and additional fertilization even increased their biomass (Figure 3B).

Why do drought and fertilization harm invertebrates much more than microorganisms? Usually, both groups are highly dependent on soil moisture and have trouble coping with droughts. Among other things, their food becomes so dry that they have difficulty digesting it [3]. Imagine eating old toast without jam all day, without drinking anything with it. To avoid drought conditions, invertebrates may travel to deeper, moister soil layers that we did not reach with our tests. However, why did fertilization lower their activity as well? The reason is that fertilization leads to an acidification of soils, which means that the $\mathrm{pH}$ value falls below five. Earthworms and many other soil invertebrates do not like to live in low-pH conditions, which can be damaging to their delicate skin. A lemon, for example, has a $\mathrm{pH}$ value of 2 . Have you ever had a cut on your finger and then gotten lemon juice on it? Not very pleasant.

The drought treatment did not harm soil microorganisms. This took us by surprise, because our treatment reduced the annual rainfall by half, which naturally led to extremely dry soils. However, we think it is possible that bacteria and fungi that normally live in the upper layer of 
the soil are constantly exposed to the temperature and humidity cycles of the seasons. For this reason, they must be able to survive even the driest periods [4]. One way that they do this is by building themselves a sugary protective shell that prevents their surfaces from drying out. Alternatively, they can create a very resistant form that allows them to survive, called a spore. Spores are in a dormant state and can outlive extreme heat and drought for up to 1,000 years. This is why we believe the drought conditions of our experiment hardly harmed the soil microorganisms. But it is also possible that our experiment was too short to see any negative effects of the drought.

Fertilization, on the other hand, was even beneficial for the microorganisms. This is because the additional nutrients from the fertilizer strongly promoted plant growth. Not only did the plants respond with longer shoots, larger flowers, and many more leaves, they also released more resources into the soil via their roots and the microorganisms could feed on all these extra food sources.

We were happy to find that drought and fertilizer did not reinforce each other's effects, which means that both factors together do not seem to do more harm than either does on its own. This may mean that ecosystems have some great coping mechanisms to use against harmful environmental attacks. But in this study, we only measured the activity of soil organisms after 1 year. We should examine the soil after many years of drought and fertilization, to see if the results are still the same.

\section{WHAT WILL THE FUTURE HOLD FOR OUR SOILS?}

To sum up, larger soil invertebrates seem to be much less well-equipped for future environmental changes than microorganisms are. What does this mean for our soils in the future? The decline in the activity of soil animals has several consequences for ecosystems and therefore for humans. As we have already learned, all organisms in the soil are necessary to keep the process of decomposition running. The decomposition process is divided into several steps, which are indispensable for one another. While invertebrates are mostly responsible for breaking down larger pieces of dead animals and plants, microorganisms digest the smaller pieces in the next step and release a range of nutrients. Together, the soil organisms form a large feeding community, in which each species has its own special place, fulfilling their specific tasks. However, if one link in this chain is missing, the whole system is likely to lose its balance [5]. This could mean that soils could lose their fertility in the long term. The result would be that not only grasses but also the wheat and maize in our fields would no longer grow so luxuriantly, and we would eventually have problems feeding all the people on Earth. We are therefore dependent on the well-being of all soil creatures and should keep 
their importance in mind as we make future decisions that could affect our soils.

\section{ACKNOWLEDGMENTS}

We thank the staff of the Bad Lauchstädt Experimental Research Station for their help in maintaining the experimental site, and Alla Kavtea, Tom Künne, and Ulrich Pruschitzki for their support with lab and field work. Furthermore, we thank the coordination of the International Drought-Net Experiment for providing protocols and support. We acknowledge editorial help by Susan Debad.

\section{ORIGINAL SOURCE ARTICLE}

Siebert, J., Sünnemann, M., Auge, H., Berger, S., Cesarz, S., Ciobanu, M., et al. 2019. The effects of drought and nutrient addition on soil organisms vary across taxonomic groups, but are constant across seasons. Sci. Rep. 9:639. doi: 10.1038/s41598-018-36777-3

\section{REFERENCES}

1. Galloway, J. N., Townsend, A. R., Erisman, J. W., Bekunda, M., Cai, Z., Freney, J. R., et al. 2008. Transformation of the nitrogen cycle: recent trends, questions, and potential solutions. Science 320:889-92. doi: 10.1126/science.1136674

2. Siebert, J., Sünnemann, M., Auge, H., Berger, S., Cesarz, S., Ciobanu, M., et al. 2019. The effects of drought and nutrient addition on soil organisms vary across taxonomic groups, but are constant across seasons. Sci. Rep. 9:639. doi: $10.1038 / s 41598-018-36777-3$

3. Thakur, M. P., Reich, P. B., Hobbie, S. E., Stefanski, A., Rich, R., Rice, K. E., et al. 2018. Reduced feeding activity of soil detritivores under warmer and drier conditions. Nat. Clim. Change 8:75-8. doi: 10.1038/s41558-017-0032-6

4. Tonkin, J. D., Bogan, M. T., Bonada, N., Rios-Touma, B., and Lytle, D. A. 2017. Seasonality and predictability shape temporal species diversity. Ecology 98:1201-16. doi: 10.1002/ecy.1761

5. Simpson, J. E., Slade, E., Riutta, T., and Taylor, M. E. 2012. Factors affecting soil fauna feeding activity in a fragmented lowland temperate deciduous woodland. PLOS ONE 7:e29616. doi: 10.1371/journal.pone.0029616

SUBMITTED: 31 March 2020; ACCEPTED: 27 August 2020;

PUBLISHED ONLINE: 08 October 2020.

EDITED BY: Helen Phillips, German Centre for Integrative Biodiversity Research (iDiv), Germany

CITATION: Sünnemann M, Siebert J and Eisenhauer N (2020) Double Whammy for Life in Soil? The Effects of Drought and Fertilizer Use. Front. Young Minds 8:547630. doi: $10.3389 /$ frym.2020.547630 

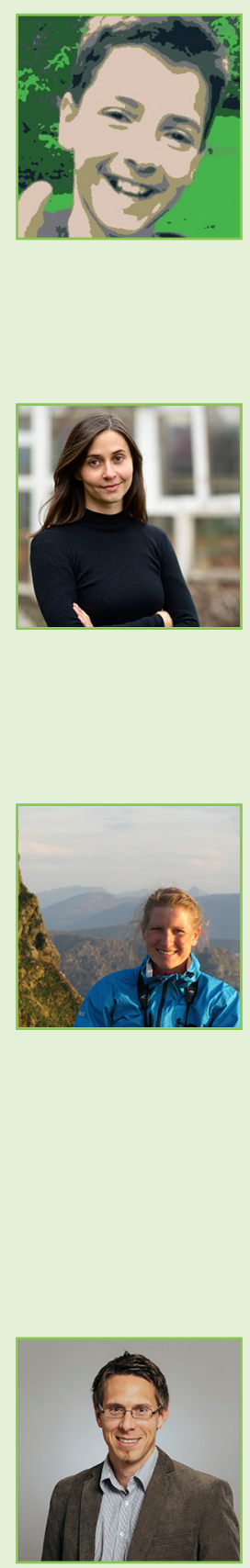

CONFLICT OF INTEREST: The authors declare that the research was conducted in the absence of any commercial or financial relationships that could be construed as a potential conflict of interest.

COPYRIGHT @ 2020 Sünnemann, Siebert and Eisenhauer. This is an open-access article distributed under the terms of the Creative Commons Attribution License (CC BY). The use, distribution or reproduction in other forums is permitted, provided the original author(s) and the copyright owner(s) are credited and that the original publication in this journal is cited, in accordance with accepted academic practice. No use, distribution or reproduction is permitted which does not comply with these terms.

\section{YOUNG REVIEWER}

\section{JEDIDIAH, AGE: 14}

Jedidiah is interested in science and math, particularly in how the environment impacts his daily life. He spends time working in the family garden, making money by selling eggs and vegetables he helps produce. In his spare time, Jed likes to play baseball and play video games.

\section{AUTHORS}

\section{MARIE SÜNNEMANN}

When she was 6 years old, her best friend challenged her to a dare: to eat an earthworm. Even though she would not do that today, her curiosity about everything that creeps and crawls belowground has never waned. Today, as a doctoral student, she studies the reactions of soil organisms to climate change in meadows and agricultural fields. In her free time, she does combat sports and enjoys being outside. *marie.suennemannaidiv.de

\section{JULIA SIEBERT}

Julia has been fascinated by nature since she was a child. She spent as much time as possible outdoors, built moss houses in the forest, and searched for all kinds of animals. She followed this passion by studying biology and communication science and was always keen on finding ways to transfer knowledge to different audiences. Her scientific studies focused on how changing climate conditions affect soil organisms and the ecosystem functions they drive. Furthermore, she explored ways to engage school students in biodiversity science. In her free time, she enjoys horse-riding, traveling, birdwatching, mountain biking, and all sorts of outdoor sports.

\section{NICO EISENHAUER}

Nico has been interested in nature since his early childhood. He dug for earthworms, caught frogs and fish, and helped lizards survive the winter months. He has always been fascinated by the beauty of nature and driven by the question of why a specific plant or animal species occurs in one place, but not in another. During his study of 
biology, he discovered his interest in soil animals and their important activities that are crucial for the functioning of ecosystems. When not at work, Nico likes playing soccer and badminton, running, and spending time with his family and friends. 